\title{
Digital financial assets and digital currency: legal nature and legal regulation of turnover
}

\author{
Boris Bashilov ${ }^{1, *}$, Marina Galkina ${ }^{2}$, and Alisa Berman ${ }^{3}$ \\ ${ }^{1}$ Peoples' Friendship University of Russia, Moscow, Russia \\ ${ }^{2}$ Kutafin Moscow State Law University (MSAL), Moscow, Russia \\ ${ }^{3}$ National Research University Higher School of Economics, Moscow, Russia
}

\begin{abstract}
In the past few years digital financial assets and digital currency have been getting more popularity among the tools of digital economy. Due to the demand for turnover of digital financial assets and digital currency, as well as the formation of an increasing number of jural relations, the object of which they are, they require efficient legal regulation, which is not a simple task for the legislator because of their dinamic development. Lack of such regulation causes the formation of non-uniform regulatory enforcements practices and the unpredictability of legal relations that are developed in relation to these instruments. One of the keys to the formation of effective regulation is a definition and precise legislative consolidation of the legal nature of digital financial assets and digital currency. This article analyzes the approaches to determining the legal nature of digital financial assets and digital currency in the current domestic legislation at the stage when such legislation has not been formed yet based on the analysis of regulatory enforcement practices and clarifications of state bodies. The current legislation is also analyzed in terms of the presence of legislative gaps taking into account the relationship between the relevant regulation and the provisions contained in other, non-major legislation. Moreover, the authors also analyzed the approaches to the regulation of the turnover of digital financial assets and digital currency abroad. Such approaches were classified as well, which allowed to identify the main trends of regulation of their turnover and to determine their legal nature.
\end{abstract}

\section{Introduction}

In recent years, we have witnessed an increase in the use of digital technologies and an increase in the number of citizens that have digital skills. The "digital revolution" is characterized by the ubiquitous use of digital technologies that become an indispensable part of all spheres of social life, ranging from daily life to the economy of the state. These circumstances determine the global trend for the formation and development of the information society of which digital economy is an indispensable part.

The digital economy is a catalyst for trade and the growth of industrial production, which allows the sector of the digital economy to take a special place in the overall array of the global economy. Because of this, the digital economy becomes an object of state strategies

* Corresponding author: information@ rudn.ru 
and long-term national programs, significant public, and private investments are attracted for its development.

The origin of the term "digital economy" is attributed to the American scientist Nicholas Negroponte within his monograph "Being Digital" of 1995 [1], in which he argues about the shortcomings of the existing model of production-sale of goods and comes to the conclusion that it is possible to optimize all stages of this process by using virtual task execution. Today, there is no uniform definition of the term "digital economy", which differs in the doctrine and legislation of the global community. For example, the Strategy of development of the information society in the Russian Federation for 2017-2030 provides the following definition of the term "digital economy" - "a business activity in which the key factor of production is the digital data, the processing of big data and the use of the results of the analysis of which, in comparison to the traditional form of management, can significantly increase the efficiency of various types of production, technologies, equipment, storage, sale, delivery of goods and services" [2].

Like any other process, digitalization of economy is impossible without the use of a certain set of instruments, i.e. the means, used to affect, create and transform the digital economy, as well as to achieve special-purpose tasks. Among the instruments of the digital economy, one can distinguish, for example, the Internet of things, big data, blockchain, artificial intelligence, digital financial assets, digital currency, etc.

Like the digital economy itself, its instruments require legal regulation, which is not a simple task for the legislator in terms of their dynamic development, a situation of "chasing" the law for modern digital and information technologies is being formed. There is often a situation in which the use of the instruments of the digital economy for a long period of time occurs outside the legal field in the absence of any state regulation, which leads to the formation of non-uniform regulatory enforcement practices and unpredictability of legal relations that are formed in relation to these instruments.

Thus, the most obvious example in this regard is the legal regulation of the turnover of digital financial assets and digital currency. The purpose of this article is the formation of practical recommendations on improvement of the domestic legal regulation of the turnover of digital financial assets and digital currency as the object of this research. To achieve this purpose, the authors set the following tasks: to describe the main stages of formation and development of legal regulation and the turnover of digital financial assets and digital currency (including through the regulatory enforcement practices) and to evaluate its current state in comparison to the national regulation in other countries.

\section{Methods}

The system of methods and approaches that are used to cover the topic of the research is determined by its object, as well by the purposes and tasks set. Taking into account the importance and complexity of the nature of the studied object, the entire complex of general, general and particular scientific techniques and methods of study, including formal-legal, comparative-legal, systematic, functional, logical, and other scientific methods including the method of the legal predicting (the formulation of scientifically-based predictions about the further development of the state-legal phenomenon made it possible to most accurately form proposals for the reform of legislation) was used as the instrumentarium of the research.

To deal with particular research problems, such modern general scientific methods as an explanation, analysis, synthesis, analogy, abstraction, deduction are widely used. Only the comprehensive use of scientific methods allowed to identify the existing legal gaps and to formulate practical suggestions for the reform of the legislation in the studied area. 


\section{Results}

The result of this research is not only the identification of the existing legal gaps of the domestic legal regulation of the turnover of digital financial assets and digital currency but also the generalization of the approaches to determining their legal nature in the period when the relevant legislation has not yet been adopted.

Moreover, in the result of the analysis of the legal regulation of the turnover of digital financial assets and digital currency in foreign countries, the authors draw conclusions about the existing approaches to their legal regulation and the definition of their legal nature in the global society. This analysis is useful from the point of view of the possibility of implementing foreign experience in regulation or, on the contrary, preventing the mistakes that were made in foreign regulation.

\section{Discussion}

For a long period of time, the role of digital financial assets and digital currency in the domestic system of objects of civil rights was not defined since they were not distinguished as an independent object of the civil law and their legal nature did not allow to attribute them to any objects that were named in the Article 128 of the Civil Code of the Russian Federation (as amended before July 18, 2019). It caused the formation of fundamentally opposite regulatory enforcement practices of courts and state bodies with regard to the issue of whether digital financial assets and digital currency are subject to civil rights and whether their turnover is not limited.

Some executors of law adhered to the logic that, according to paragraph 1 of Article 75 of the Constitution of the Russian Federation, the monetary unit in the Russian Federation is the ruble. Thus, the only ruble is a legal means of payment (Article 140 of the Civil code of the Russian Federation). In this regard, the Ministry of Finance of the Russian Federation [3] and the Central Bank of the Russian Federation [4] in their explanations indicated that digital currency (for example, bitcoin) is a monetary surrogate and its introduction and circulation on the territory of the Russian Federation in accordance with Article 27 of the Federal Law "On the Central Bank of the Russian Federation (Bank of Russia)" is prohibited. This point of view was also confirmed by the litigation practice [5].

Others supported the point of view that digital currency can not be classified as a monetary asset since it is neither the currency of the Russian Federation nor the foreign currency (as it is understood from Paragraphs 1 and 2 of Part 1 of Article 1 of the Federal Law "On Currency Regulation and Currency Control"). Moreover, the emission and accounting of the digital currency, the accounting of the transactions with it is decentralized, by automatically making entries in the distributed registers of the participants of the blockchain network. In this regard, both the emission of digital currency and transactions with it can not be controlled by states, organizations or individuals.

Moreover, they drew a conclusion that, despite the fact that digital currency is not a legal mean of payment as it is understood in the current legislation of the Russian Federation, its turnover is not directly limited by law and it is not subject to civil rights (as "other property" as it is understood by Article 128 of the Civil Code of the Russian Federation).

In October 2017, the President of the Russian Federation, as part of the implementation of the program "Digital Economy of the Russian Federation", instructed the Government of the Russian Federation and the Bank of Russia to ensure that the legislation of the Russian Federation is amended to define the status of digital technologies used in the financial sector and their terms, based on the obligation of the ruble as the only legal means of payment in the Russian Federation [6]. In this regard, the work on the draft law No. 419059-7 was initiated. 
The result of the amendment of the legislation was the adoption of the Federal Law of July 31, 2020, No. 259-FZ "On digital financial assets, digital currency and on amendments to certain legislative acts of the Russian Federation" (hereinafter referred to as Law No. 259FZ), according to which two categories are distinguished: digital financial assets as "digital rights" (including monetary demands, the ability to exercise rights under emission securities, the right to participate in the capital of a non-public joint-stock company and the right to demand the transfer of emission securities) and digital currency as "a set of digital data".

It should be noted that in its original version the draft law No. 419059-7 acknowledged digital currency as a type of digital financial assets, however, there is no direct indication of this in the final version of Law No. 259-FZ. At the same time, the correlation between digital financial assets and digital currency is complicated and incorrect, since they, being digital rights and electronic data respectively, have different legal nature and are independent objects [7].

The Council of the Federation Budget and Financial Markets Committee in its conclusion on the draft law No. 419059-7 indicated the following considerable difference between digital financial assets and digital currencies: "with regard to a digital financial asset, there is always an obligated person on demand (obligation) who certifies a digital financial asset, at the same time, there is no obligated person with regard to the digital currency, just as there is no requirement (obligation) underlying it." At the same time, a digital financial asset as a type of digital right is subject to civil rights, and in this regard can act as a legal object of civil transactions" [8].

It seems that these conclusions lead to the fact that digital currency can not be acknowledged as an object of civil rights. However, it directly contradicts, for example, part 6 of Article 14 of Law No. 259-FZ, which enshrines the possibility of making civil transactions and/or operations with digital currency. Moreover, for the purposes of a number of legislative acts (for example, the Federal Laws "On combating legalization (laundering) of criminally obtained incomed and financing of terrorism", "On insolvency (bankruptcy)", "On enforcement proceedings", "On combating corruption") the digital currency is recognized as property. However, in the current version of Article 128 of the Civil code of the Russian Federation, only digital rights (as property rights), i.e. digital financial assets, are recognized as an object of civil rights, but not digital currency.

Thus, there is a contradiction, according to which in particular laws and regulation the digital currency is recognized as property, in respect of which civil transactions and operations can be made, however, as understood by civil law, digital currency is still not an object of civil rights.

This legislation gap is also noted by the State Duma Committee on the Financial Market in its conclusion on draft law No. 419059-7: "Taking into account that the draft makes amendments to particular laws of the Russian Federation concerning the recognition of digital currency as property for the purpose of their use, it is also necessary to make amendments of a corresponding nature in the provision of the Civil code of the Russian Federation as part of referring digital currency to objects of civil rights" [9].

The identified legal gap requires making relevant amendments to the legislation in order to form a unified approach to the regulation of one of the fundamental instruments of the digital economy.

Studying the nature of digital financial assets and digital currency, it should be noted that their legal regulation considerably varies in many countries of the world. At the same time, in some countries, there is no such concentration, which is temporary in nature and supplemented by explanations from various state authorities until the relevant regulation is adopted. In some countries like, for example, China, Bangladesh, Bolivia, Venezuela, Vietnam, Egypt, Iceland, Kyrgyzstan, Ecuador, etc., there is a ban on the use of digital 
currency, which means that there were no attempts to determine its legal nature at the legislative level.

Consider approaches to determining the legal nature of digital financial assets and digital currency in those foreign countries that have adopted specialized legal regulation. Among these countries, there are, for example, Japan, the Philippines, some states of the USA (for example, Washington, New York, South Carolina, Georgia, Pennsylvania, New Mexico, New Hampshire, etc.), Germany, Switzerland, UAE, Australia, Canada, etc.

For example, in the USA the Security and Exchange Commission recognized cryptocurrency as both means of payment, property (for example, for the purpose of taxation), and exchange goods [10]. At the same time, its legal regulation and determining of its legal nature can vary depending on the state. Moreover, the USA has introduced requirements for licensing exchange sites as financial services companies, as well as requirements for identifying users.

These requirements in terms of licensing and identification of users are common in Canada, Germany, and Switzerland, but in Switzerland, there is also an alternative to licensing - membership in a self-regulatory organization. In the UK and Singapore, these provisions are still only advisory in nature.

In Japan, cryptocurrency is defined as "a digital property holding" that is accepted as means of payment but not equated to either currency or electronic money. Exchange platforms are also subject to licensing, but they have a separate type of license of Financial Services Agency (FSA) - licenses for payment service providers for the exchange of virtual currencies. To acquire this license, this site must meet the minimum capital requirements. The users are subject to identification when opening an account on the site, as well as when having transactions above the set limits.

In Australia, the relevant legislation is being developed, but there is already the Code of Conduct of Participants of the Market of Cryptocurrency (for these purposes a self-regulatory organization was created), which sets the requirements for registration of not only exchange platforms but also of cryptocurrency wallet providers and a requirement to identify users.

In the Philippines, cryptocurrency is recognized as a means of payment. The requirement to register exchange platforms as payment service providers is fixed, the requirement to identify users is also provided. There is an administrative responsibility for non-compliance with these requirements.

\section{Conclusion}

Thus, the legislative ban on the turnover and the use of digital financial assets and digital currency in the range of countries is mostly an exception. Most countries of the world are at the stage when the turnover and the use of digital financial assets and digital currency is not regulated yet, but there is work on the development of the relevant legislation, or at the stage when the relevant specialized regulation has already been adopted. The legal nature of digital financial assets and digital currency is not always directly enshrined in the adopted legislation, but their legal nature can be derived from provisions, for example, on registration (licensing) of exchange platforms, taxation of participants in turnover, etc.

Approaches to determining the legal nature of digital financial assets and digital currency vary from country to country. For example, the analysis of foreign legal regulation of cryptocurrency turnover revealed the following approaches to determining its legal nature: means of payment, digital property holding, property, and commodity. It seems that this list of approaches is not comprehensive and can be expanded with the adoption of new regulations in other countries.

In recent years in the Russian Federation, the formation of special legislation on digital financial assets and digital currency that is far from being perfect and contains a range of 
legal gaps, and therefore, potentially in the near future, will be subject to amendments, but it already contributes to the formation of a uniform practice and gives rise to certain predictability required for participants in civil transactions. At the same time, the adoption of relevant legislation creates the need to amend existing regulations in order to bring them into compliance with the new regulation.

It also concerns the previously identified contradiction, according to which in particular laws and regulation the digital currency is recognized as property, in respect of which civil transactions and operations can be made, as understood by civil law, digital currency is not an object of civil rights. This contradiction requires a prompt response from the legislator, taking into account the dynamic development of this legal instrument.

This work was financially supported by the Grant of the President of the Russian Federation No. HШ2668-2020.6 "National-Cultural and Digital Trends in the Socio-Economic, Political and Legal Development of the Russian Federation in the 21st Century".

\section{References}

1. N. Negroponte, Being Digital, NY: Knopf, 256 (1995)

2. Decree of the President of the Russian Federation "On the Strategy for the Development of the Information Society in the Russian Federation for 2017-2030" dated May 9, 2017, No. 203, Official Gazette of the Russian Federation. 2017 No. 20. Article 2901

3. Letter of the Ministry of Finance of Russia dated October 02, 2017, No. 03-11-11/63996

4. Information of the Bank of Russia dated January 27, 2014 "On the use of "virtual currencies" in transactions, in particular, Bitcoin"

5. Determination of the Arbitration Court of the Tyumen Region dated June 22, 2016, in case No. A70-15360/2015

6. List of instructions following a meeting on the use of digital technologies in the financial sector, President of Russia. http://kremlin.ru/acts/assignments/orders/55899.

7. A.A. Sitnik, Actual problems of Russian law 11, 105 (2020)

8. Conclusion of the Federation Council Committee on Budget and Financial Markets on the Federal Law "On Digital Financial Assets, Digital Currency and on Amendments to Certain Legislative Acts of the Russian Federation" (draft No. 419059-7) dated July 23, 2020, No. 3.5-03/1230, Legislative support system. https://sozd.duma.gov.ru/bill/419059-7

9. Conclusion of the State Duma Committee on the Financial Market on the Federal Law "On Digital Financial Assets, Digital Currency and on Amendments to Certain Legislative Acts of the Russian Federation" (second reading, repeated) dated July 17, 2020, No. 3.24-6/820, Security System legislative activity. https://sozd.duma.gov.ru/bill/419059-7

10. Investor Bulletin: Initial Coin Offerings, U.S. Securities and Exchange Commissions. https://www.sec.gov/oiea/investor-alerts-and-bulletins/ib_coinofferings

11. E.P. Rusakova, E.E. Frolova, A.I. Gorbacheva, Advances in Intelligent Systems and Computing 1100, 669 (2020)

12. A.O. Inshakova, E.E. Frolova, M.V. Galkina, E.P. Rusakova, Int. J. of Sociology and Social Policy, 9 (2020) 